\title{
National Technology Initiative as a Platform for the Diffusion of Convergent Technologies in the Russian Mining Industry
}

\author{
Elena Dotsenko, ${ }^{1,}$, Natalia Ezdina ${ }^{1}$, Oksana Galiuta $^{2}$, and Michal Cehlar ${ }^{3}$ \\ ${ }^{1}$ Plekhanov Russian University of Economics, Department of Political Economy and History of \\ Economic Science, 117997 Moscow, 36 Stremyanny lane, Russia \\ ${ }^{2}$ Surgut State University, 628417 16-116 Lenin Av., Surgut, Russia \\ ${ }^{3}$ Technical University Košice, Faculty BERG, Letná 9, 04001 Košice, Slovakia
}

\begin{abstract}
In recent decades, the global processes of technological development of industry, due to innovative modernization, have become comprehensive, affecting both manufacturing and raw materials industries. One of the components of global technological modernization is technological convergence - the combination of technologies from different industries, resulting in a inter-industry genesis of new production methods. Despite the fact that technological convergence is transforming, first of all, the industries associated with the deep processing of raw materials and highly intelligent intangible production, mining industry is in the greatest need for modernization. This is due to turbulent demand and volatile prices for mineral resources in the global market, with the widespread introduction of energy and resource saving technologies. Therefore, the mining sector of the Russian economy is looking for a "fulcrum" in initiating the diffusion of convergent technologies in mining and management processes of industrial enterprises. This "fulcrum" is intended to be the National Technology Initiative, the key target markets of which are fully consistent with the technological requirements of the Russian mining complex.
\end{abstract}

\section{Introduction}

Currently, sustainable development on a global scale is impossible without the diffusion of innovations created in advanced countries into various industries and sectors [1]. In the modern economy, global technological leadership occupies a higher level in the hierarchy of needs [2]. However, the formulation of innovative development in most strategic Russian documents demonstrates only the ambitiousness of the plans, but not their specific application [3]. This approach is prudent, but national innovation strategies without tangible link to resource industries cannot receive public support. The consensus opinion of experts regarding the prospects for the development of the world mining industry is such that the entire sector of mineral raw materials extraction is under pressure today [4-6]. In the long term, the fall in commodity prices squeezes the cash flows of international corporations by $12-20 \%$, and national holdings and enterprises - by $25-30 \%$ [7-8]. This hinders investment

\footnotetext{
${ }^{*}$ Corresponding author: ktyf110372@rambler.ru
} 
in the technological modernization of mining enterprises, as a result of which, in the last decade, there has been a decrease in labor productivity in the global mining sector [9-10]. At the same time, one cannot deny the breakthrough nature of the Russian National Technology Initiative, which is designed to determine promising directions for the development of both the manufacturing and the raw materials sector. The National Technology Initiative is defined as "a program of measures to form fundamentally new markets and create conditions for the global technological leadership of Russia by 2035" [11]. "Global technological leadership" occupies a higher level in the hierarchy of needs - at the level of recognition (self-esteem, confidence, achievement). The authors of the concept point to the unknown markets that will receive global development in 20 years, therefore the National Technology Initiative is working on those projects that can potentially become key in future markets [11].

The convergent technological modernization of the raw materials sector is called upon to become such a tangible goal. In principle, the structure of the National Technology Initiative includes markets directly related to mining - EnergyNet (digitalization of mining), AeroNet (use of unmanned aerial vehicles to improve the accuracy of mining and technical calculations), NeuroNet (artificial intelligence in the management of technological and business-processes).

The potential for a new breakthrough in increasing the economic efficiency and competitiveness of the Russian extractive sector in the global economy is determined by its deep technological modernization [12-14]. At present, the specific productivity of equipment used in the mining sector is increasing by $10-12 \%$ every 5 years, which is especially typical for open pit mining [15-16].

New ways of organizing mining operations are now becoming available thanks to digital and technological innovations that transform the traditional organization of mining operations into an innovative one [17-18]. The vector that sets the prospects for the development of the mining sector is technological convergence, which forms a single area of knowledge from different industries through the merger of technologies. The most advanced form of technological convergence is NBICS-convergence, which combines information technology and artificial intelligence, as well as bio- and nanotechnology [19-21]. The key area of convergence in the mining sector, in our opinion, is the combination of information and cognitive technologies with traditional geotechnology.

Thus, the National Technological Initiative is intended to become a platform on which the latest achievements of domestic fundamental science will take a form corresponding to the conditions of diffusion of innovations in the mining sector.

\section{Materials and Methods}

The convergence of information and cognitive technologies will allow a modern mining industry to meet new challenges:

1. Optimization of the volumes of solid minerals extraction and direct costs in the context of increasing instability in demand for raw materials in the world as a whole, through closer linking of the volume of mining operations at mining enterprises to the output of the final product - energy, metals, chemical components [ 22-24].

2 . Reducing the impact of the instability of the global and local raw materials markets on the procurement of material resources by mining enterprises by improving the system of strategic and operational planning taking into account the maximum possible number of factors and integrating technological and economic modeling of mining operations.

3. Automation of the management of mining processes at a specific enterprise, pursuing a set of goals, including labor safety, raw materials quality, equipment productivity improving. [25] 
The main areas of diffusion of convergent technologies in the activities of the extractive sector enterprises include the following:

- artificial intelligence systems in the management of mining enterprises in general, and specific processes in particular. For example, a significant proportion of engineering and management decisions are associated with the variability of quality of the mineral in the array. Therefore, taking into account all the factors affecting the quality of raw materials from the face to the processing plant and then to the consumer requires the analysis of large data sets and the generation of many decision-making scenarios. This, in turn, requires widespread use of a neural network as a form of organizing the calculations of technological parameters, determining the operating mode of equipment, its load in time;

- integration of mining processes based on ultra-fast exchange and analysis of the information and complex calculations in real time. This means a widespread digitalization of the main and auxiliary processes of mining, the creation of complex and interconnected digital models that allow optimizing mining technologies in such a way that the changes made do not reduce the productivity of the enterprise as a whole and do not increase non-production costs. To comply with these conditions, the digitalization of mining operations should be based on the massive use of telemetry and mobile sensors, which allow not only tracking processes in real time, but also making reliable forecasts based on cloud data analysis;

- automated planning of mining operations, formation of work assignments and control of their implementation using intelligent devices and equipment, united by a neural network into a single corporate artificial intelligence system. It allows autonomous tuning, selfdiagnostics and regulation of operating parameters, with complete transparency of the implementation of plans in real time, providing visibility of the volumes of resources used and extracted raw materials;

- creation of centres for remote control of minerals extraction and their supply to consumers.

For example, when the level of coal reserves at a power plant becomes low, automated mining enterprises receive information about the need to ship coal, as a result of which current and annual mining plans are adjusted through a single central control room. At the same time, a high level of visualization of remote control allows you to combine and reduce to simple and understandable indicators the entire array of information coming from a variety of sensors. [4] This means the possibility of designing and creating deeper quarries and mines without increasing technical, economic risks and reducing the level of labor safety.

Diffusion of convergent technologies in the extraction of minerals in the framework of the implementation of these areas implies the widespread introduction of a number of convergent information and cognitive technologies:

1. Artificial intelligence, combining progressive methods of machine learning and the use of the widest range of mathematical and analytical methods for data analysis and integration. The use of information-convergent artificial intelligence technologies helps turn gigantic sets of data into an estimation of the likelihood of future events. For example, complex tasks of managing mineral extraction technologies, such as geological modeling, operational planning, forecasting equipment accidents, natural and man-made tectonic isturbances, are increasingly becoming the subject of intelligent analysis algorithms.

2. New technologies of human-and-machine interaction, reducing the presence of a person in the mining area. One example is smart goggles. They give instructions to workers of mines and open-pit mines or personnel performing equipment repairs, based on online digitization and automatic analysis of incoming video and photo information using a neurolink. The use of such glasses, created by the Austrian company E-Mine Systems, greatly improves the quality of work. Another example is workwear, which includes sensors that transmit data to engineers about hazardous conditions and the physical condition of workers themselves, which improves safety performance. 
3. Digital-and-physical conversion of reality and the use of augmented reality algorithms. In the mining industry, the use of remote control equipment becomes routine in many large enterprises, and the use of fully autonomous equipment is becoming more and more popular. In particular, companies such as the Australian Industrial Robot Center, Sandvik Mining, Atlas Copco have been producing fully autonomous underground and surface loaders since 2013. Fully autonomous mining dump trucks have been produced by Komatsu AHS since 2013, more than 450 of these machines are going to be produced by 2022 [27].

4. "Internet of Things" as part of the platform of the latest industrial technologies "Industry 4.0", which is actively implemented in the mining industry around the world. Along with the widespread introduction of various telemetry systems and sensors in equipment management and labor safety, in recent years, methods for analyzing the Earth's gravitational field using drones in geological exploration have been used (VK1 airborne gravity gradiometer technology, developed at the University of Western Australia), 3D laser scanning methods (CAE Sirovision, ARANZ, Avizo Fire, ABB and Atlas Copco).

Of particular note is the expansion of the scope of application of "nano-bio" convergent technologies in mining, in particular, the use of copper-eating bacteria for the development of substandard copper reserves with subsequent chemical extraction of the useful component (developed by the University of Sao Paulo, Brazil) [28].

\section{Results and Discussion}

The convergent technological basis for the modernization of mining operations is capable of providing a fundamental shift in the productivity of the mineral resource complex. The diffusion scheme of convergent "info-cogno" technologies in the extractive sector in order to increase the labor productivity of mining enterprises is shown in Fig. 1.

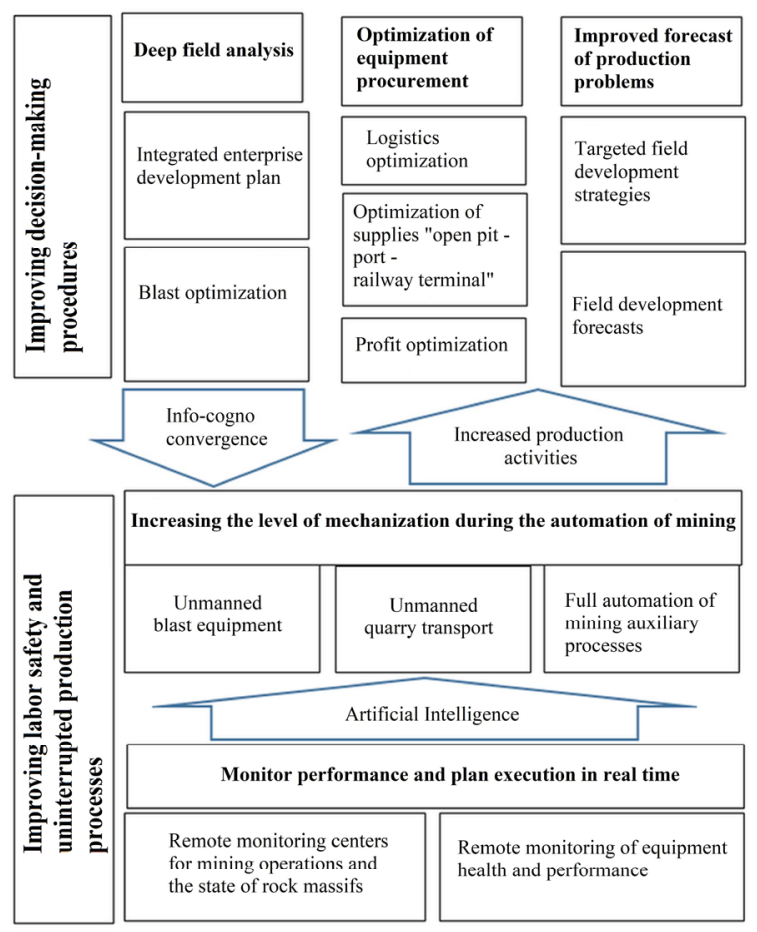

Fig. 1. Diffusion of convergent "info-cogno" technologies in the development of mining. 
Shown in Fig. 1 scheme of diffusion of technological convergence "info-cogno" in the mining sector reflects the process of increasing productivity as a result of deep informatization of mining processes and automation based on artificial intelligence, reducing uncertainty in making engineering and production and economic decisions.

The integration of digital technologies in production processes and economic indicators management based on artificial intelligence contains a solution to the problem of underutilization of information at mining enterprises, when no more than $10 \%$ of information is available to engineers and managers [24]. Comprehensive digitalization and automation of all technological processes can solve the problem of losing information about the state of mining operations, mineral reserves and the dynamics of its extraction, as well as about trends in the raw material market. Reducing the level of information loss, accelerating its analysis will not slow down the result in the form of reducing productivity losses and reaching its actual values of maximum marks. This, in turn, requires a transition from the existing work scheduling system based on the available mineral reserves to an online scheduling system. The introduction of automated mining planning methods in real time based on artificial intelligence can improve productivity by optimizing and integrating geological exploration and mine surveying data, rock strength of the drilling and blasting unit, duration of excavation cycles and dump trucks exchange time, mining position.

Integration of information on the economic state of the subsoil, the processes of its extraction, transportation and storage of overburden and minerals, as well as its further use into a single databank, can optimize technological processes, reduce losses of minerals and improve its quality. The convergence of data acquisition technologies and real-time intelligent analytics enables planning and decision-making that maximizes equipment utilization and productivity over time. The combination of traditional dispatching with intelligent algorithms allows introducing of mining clustering technologies and distinguishing segments of high and low productivity, intense and rare equipment failures.

All this makes it possible to create the foundation for almost complete automation of most mining processes. If today automated road transport and drilling equipment are fully implemented in Australia, Canada, the USA, then automated blasting and excavation operations are at the testing stage. Nevertheless, a key aspect of their implementation is the integration of ever-increasing flows of information and artificial intelligence systems for its analysis and implementation in engineering decisions. It is assumed that the introduction of convergent technologies for the extraction of solid minerals will increase labor productivity by $40 \%$ and reduce operating costs by $30 \%$, which will help stabilize the development of both the global mineral sector and mining industry in resource-rich countries [29-30].

\section{Acknowledgement}

This study was financed by a grant from the Plekhanov Russian University of Economics.

\section{Conclusion}

The processes of minerals extraction, as well as the business processes of mining enterprises, are characterized by uncertainty due to its dependence on the geological characteristics of deposits, the stability of natural and man-made massifs, failure of high-performance equipment, and the human factor. To date, this technological uncertainty has been exacerbated by uncertainty of future demand and prices for minerals, especially fossil fuels. This, along with the gradual depletion of the deposits operated since the middle of the 20th century and the complication of the mining and geological conditions for the extraction of minerals, served to reduce the productivity of many mining enterprises and made them 
defenseless against the crisis caused by raw materials economic supercycle. Therefore, the response to the unstable world demand for raw materials, the global trend of decarbonization, and the development of recycling and lean production should be deep technological modernization, improving geotechnology in the direction of technological convergence. Scientific and technological centers created within the framework of the National technology initiative should become "points of growth" for breakthrough convergent technologies necessary for informatizing mining enterprises and saturating them with artificial intelligence.

\section{Acknowledgement}

The study was supported by Plekhanov Russian University of Economics.

\section{References}

1. S. Zhironkin, M. Gasanov, G. Barysheva, E. Gasanov, O. Zhironkina, G. Kayachev, E3S Web of Conferences 21, 04002 (2017)

2. K. Čulková, H. Pavolová, S. Khouri, L.G. Shut'ko, Economics and Innovation Management 3, 77-87 (2020) DOI: 10.26730/2587-5574-2020-3-77-87

3. S. Zhironkin, O. Aleshina, V. Gorev, Y. Gunyakov, O. Zhironkina. E3S Web Conferences 105 (2019) 04001

4. M. Andrzejewski, P. Dunal, L. Poplawski, Acta Montanistica Slovaca 24(1), 53-62 (2019)

5. M. Cehlár, P. Rybár, J. Mihók, J. Engel, Journal of Mining and Geotechnical Engineering 1, 4-31 (2020) doi: 10.26730/2618-7434-2020-1-4-31

6. A.N. Tokarev, Economics and Innovation Management 3, 46-51 (2017) DOI: 10.26730/2587-5574-2017-3-46-51. DOI: 10.26730/2587-5574-2017-2-11 -23

7. S.A. Zhironkin, Ugol' 6, 62-63 (2001)

8. M. Cehlár, J. Janočko, Z. Šimková, T. Pavlik, Assessment process of concept for mining and its impact on the region E3S Web of Conferences 15, 01019 (2017)

9. N.K. Sedykh, I.N. Tchaikovskaya, Economics and Innovation Management 1, 74-83 (2021) DOI: 10.26730/2587-5574-2021-1-74-83

10. S.K. Demchenko, J.J. Suslova, A.S. Yamschikov, I.R. Ruyga, T.A. Melnikova, Journal of Applied Economic Sciences 12(1), 194-205 (2017)

11. National Technology Initiative. Russian Federation. URL: https://nti2035.ru/nti/

12. Amirova N., Sargina L., Khasanova A., E3S Web of Conferences 174, 02011 (2020)

13. Dotsenko, E. E3S Web of Conferences 21, 04013 (2017)

14. Dotsenko, E., Ezdina, N., Mudrova, S. E3S Web of Conferences 105, 02008 (2019)

15. M. Tyulenev, S. Zhironkin, E. Tyuleneva, A. Abay, S. Anyona, M. Hellmer, Coal International 265(3), 30-34 (2017)

16. S. Zhironkin, A. Selyukov, M. Gasanov, Energies 13(13), 3305 (2020)

17. O. Kalenov, S. Kukushkin, E3S Web of Conferences, 174, 02024 (2020)

18. S. Kukushkin, O. Kalenov, R. Kamanina, O. Kosareva, E3S Web of Conferences 174, 04014 (2020) 
19. M.C. Roco, W.S. Bainbridge, Converging technologies for improving human performance: nanotechnology, biotechnology, information technology and cognitive science (Kluwer Academic Publishers, New York, 2003)

20. S.A. Zhironkin, K.A. Kolotov, A.E. Genin, F.V. Agafonov, S.A. Kovalevsky, IOP Conference Series: Earth and Environmental Science 50(1), 012011 (2017)

21. S. Zhironkin, S. Demchenko, G. Kayachev, E. Taran, O. Zhironkina, E3S Web of Conferences 105, 03008 (2019)

22. M. Beer, R. Rybár, M. Cehlár, S. Zhironkin, P. Sivák, Energies 13(10), 2450 (2020)

23. P. Sivák, P. Tauš, R. Rybár, M. Beer, Z. Simkova, F. Banik, S., Zhironkin, J. Citbajová, Energies 13(15), 3878 (2020)

24. F. Abu-Abed, E3S Web of Conferences 105, 03006 (2019)

25. S. Zhironkin, M. Gasanov, G. Barysheva, K. Kolotov, O. Zhironkina, The innovative development of machine building as a driver of import substitution E3S Web Conferences 15, 03012 (2017)

26. V.V. Guzyr', Economics and Innovation Management 4, 4-19 (2019) DOI: 10.26730/2587-5574-2019-4-4-19

27. D. Dubinkin, V. Aksenov, M. Tyulenev, S. Markov, Journal of Mining and Geotechnical Engineering 4, 42-69 (2020) doi: 10.26730/2618-7434-2020-4-42-69

28. T.V. Kiseleva, V.G. Mikhailov, Ya.S. Mikhailova, Economics and Innovation Management 1, 63-73 (2021) DOI: 10.26730/2587-5574-2021-1-63-73

29. M. Cehlar, Economics and Innovation Management 3, 24-31 (2019) DOI: 10.26730/2587-5574-2019-3-24-31

30. L. Khayrulina, D. Savrasova, M. Zhidkova, E3S Web of Conferences 174, 04048 (2020) 